\title{
Antibodies to Core Lipopolysaccharide Determinants: Absence of Cross-reactivity with Heterologous Lipopolysaccharides
}

\author{
D. Heumann, J. D. Baumgartner, \\ H. Jacot-Guillarmod, and M. P. Glauser
}

\author{
Division of Infectious Diseases, Department of Internal Medicine, \\ Centre Hospitalier Universitaire Vaudois, Lausanne; Hoffmann-La Roche, \\ Basel, Switzerland
}

\begin{abstract}
Using monoclonal antibodies directed against defined epitopes of endotoxin core, this study demonstrated that the presentation of lipopolysaccharide (LPS) to antibodies is critical for measuring the specific binding of antibodies to LPS structures. False cross-reactive reactions apparently were observed when free core LPS or lipid A were used as antigens in ELISA, whereas coating with complexes of high-density lipoproteins with core LPS increased both the sensitivity and the specificity of the test compared with coating with free core LPS, so that nonspecific binding of antibodies was largely avoided. Using this technique, it was not possible to find broadly cross-reactive core LPS antibodies after immunization of rabbits and humans with rough mutants of gram-negative bacteria. These observations underscore the need for careful evaluation of the potential for cross-reactivity of antisera and of monoclonal antibodies directed against endotoxin core.
\end{abstract}

The core region of lipopolysaccharides (LPS) is relatively similar in structure among various gram-negative bacteria, whereas the outermost $\mathrm{O}$-side chains are responsible for the marked antigenic diversity of gram-negative bacteria. $\mathrm{O}$-side chain-specific antibodies afford a strain-specific protection but do not protect against heterologous strains in animal models. The core region of LPS is exposed at the surface of the O-side chains lacking rough mutants, among which Escherichia coli J5 and Salmonella minnesota R595 have been the most studied. After immunization with such mutants, antisera of rabbits or humans contain antibodies directed against core LPS. These antisera have been reported to protect against challenge with heterologous gram-negative bacteria or smooth LPS [1-5]. However, the demonstration that protection is due to core LPS antibodies has not been convincingly put forward so far, especially because of the difficulty in unequivocally demonstrating cross-reactions between core LPS antibodies and purified LPS extracted from heterologous stationary-phase bacteria [1, 6-13].

Investigations of the role of cross-reactive antibodies in immunity to endotoxins require an accurate and specific assay for antibodies directed against the various epitopes of core LPS and lipid A. A number of serologic tests have been proposed to measure these antibodies, including immunofluorescence $[14,15]$, passive hemagglutination $[3,16-18]$, and passive hemolysis [19-23]. In recent years, core LPS anti-

Received 21 November 1988; revised 18 October 1990.

Grant support: Fonds National Suisse de la Recherche Scientifique (3.825-0.86, 32-25550.88).

Reprints or correspondence: Dr. J. D. Baumgartner, Division of Infectious Diseases, CHUV, CH-1011 Lausanne, Switzerland.

The Journal of Infectious Diseases 1991;163:762-768

(c) 1991 by The University of Chicago. All rights reserved.

0022-1899/91/6304-0014\$01.00 bodies have usually been measured by ELISA. Polyclonal rabbit antisera raised against core LPS and lipid A [9, 10, 17, 24-26], murine monoclonal hybridomas selected against core LPS or lipid A [12, 27-30], and human sera from normal volunteers and patients [31-34] were analyzed by this technique. These tests were done with LPS diluted in aqueous buffers as coating antigen. However, due to the limited solubility and self-aggregating properties of amphiphilic core LPS or lipid A, this procedure might induce a poorly reliable coating of the antigen and an increase in the nonspecific binding of immunoglobulins [23]. To immobilize antigen at the bottom of the wells, some techniques have relied on a chemical treatment before coating, which may modify or delete epitopes. Another proposed method has been to use core LPS and lipid $A$ in association with bovine serum albumin to improve the coating [35-37].

In the present study, we investigated various ELISA methods for demonstrating cross-reactive antibodies against endotoxin core. To obviate the potential nonspecific binding of antibodies to the hydrophobic structures of LPS, we complexed LPS with high-density lipoproteins (HDL), a natural carrier in vivo of LPS both in animals and humans $[38,39]$. The use of complexes of LPS or lipid A with HDL has three theoretical advantages: (1) a better coating of the plastic due to the protein carrier effect, (2) a removal of LPS contaminants (e.g., proteins and nucleic acids) during the ultracentrifugation step used to purify LPS-HDL complexes, and (3) a more physiologic presentation of the antigen since LPS is rapidly complexed with HDL in the circulation [38,39].

We compared the binding of antibodies to LPS-HDL complexes with the binding to free LPS or lipid A. We used monoclonal antibodies directed against precisely defined epitopes of core LPS to determine the accuracy of the binding observed with the various antigen preparations. Finally, using the various ELISA techniques, we investigated the development of 
cross-reactive antibodies after immunization of animals and humans with $E$. coli J5.

\section{Material and Methods}

LPS and bacteria. E. coli O111:B4, E. coli J5, S. minnesota $\mathrm{S} 128$ and its rough mutants were gifts from E. J. Ziegler (San Diego). LPS from $E$. coli O111:B4 (O111 LPS) was obtained from Sigma Chemical (St. Louis). LPS from $E$. coli J5 mutant (J5 LPS), LPS from S. minnesota R595 mutant (Re LPS), and lipid A from S. minnesota R595 mutant (lipid A) were obtained from Ribi Immunochem Research (Hamilton, MT). Lyophilized powders were reconstituted at a concentration of $1 \mathrm{mg} / \mathrm{ml}$ in pyrogen-free water, with $0.5 \%$ ( $\mathrm{vol} / \mathrm{vol}$ ) triethylamine for Re LPS and lipid A. For preparation of radiolabeled LPS, $E$. coli $\mathrm{O} 111: \mathrm{B} 4$ and $E$. coli J5 were grown in trypticase soy broth containing $10 \mathrm{mCi}\left[{ }^{3} \mathrm{H}\right]$ acetate/l, and LPS was extracted by the water-phenol method [40]. [ $\left.{ }^{3} \mathrm{H}\right] \mathrm{LPS}$ from $S$. minnesota R595 was a gift from R. J. Ulevitch (San Diego). Lipid A (0.5 mg; Ribi) was labeled with $100 \mu \mathrm{Ci}{ }^{51} \mathrm{Cr}$ [41].

Immunizations. Boiled $E$. coli $\mathrm{O} 111: \mathrm{B} 4$ and $E$. coli $\mathrm{J} 5$ bacterial cells were suspended in $0.15 \mathrm{M} \mathrm{NaCl}$ and adjusted spectrophotometrically to a concentration of $5 \times 10^{9}$ cells $/ \mathrm{ml}$ (22\% light transmission at $610 \mathrm{~nm}$ ). New Zealand rabbits were immunized with six intravenous injections of $1 \mathrm{ml}$ of boiled cells administered during a 2-week period. Samples of serum were collected 7 days after the last injection. Lipid A and Re LPS vaccines were prepared by reacting $10 \mathrm{ml}$ of sheep red blood cells with $5 \mathrm{ml}$ of lipid A or Re LPS at $1 \mathrm{mg} / \mathrm{ml}$. After extensive washing in $\mathrm{NaCl}(0.9 \%), 0.5 \mathrm{ml}$ of sensitized sheep red blood cells were given intravenously three times per week for 2 weeks and the postimmunization serum was obtained 7 days after the last injection. Healthy human volunteers were immunized with $\mathrm{J} 5$ vaccine (provided by E. J. Ziegler) as described $[4,5]$.

Monoclonal antibodies. Mouse monoclonal antibody $\mathrm{Cl17}$ (IgG2b), a gift from B. J. Appelmelk (Amsterdam) was obtained by immunizing mice with $S$. minnesota $R 595$ [42]. It recognizes an epitope consisting of parts of the 3-deoxy-D-manno-2-octulosonic acid (KDO) disaccharide and lipid A; it is specific for Re LPS but specificity for lipid A alone is absent [43]. Clones 8A1 (IgG1) and 1C3 (IgG3, an isotype switch variant of 8A1 with the same specificity), developed by Centocor (Malvern, PA), were provided by HoffmannLa Roche (Basel, Switzerland); they were from immunizations of mice with heat-killed $E$. coli J5 boosted with a mixture of J5 LPS and Re LPS. Both of the latter monoclonal antibodies are directed against a yet undefined epitope within the lipid A structure $[29,30]$. The two human IgM hybridomas F117 and F136 were obtained by one of us (H. J.-G.) from fusions of a human heteromyeloma cell line with peripheral blood lymphocytes of human volunteers vaccinated with heat-killed $E$. coli J5 bacteria. F117 is directed against a yet undefined epitope of the lipid A, and F136 exclusively recognizes the J5 LPS core, as revealed by immunoblotting techniques.

Affinity purification of human J5 LPS antibodies. Plasma obtained from human volunteers immunized with heat-killed $E$. coli $\mathrm{J} 5$ bacteria [5] were screened by ELISA, selected for high titer of antibody against J5 LPS, and pooled. A high-titered pool was used for purification of immunoglobulins. After enrichment of immunoglobulins by precipitation of the pool with saturated $\left(\mathrm{NH}_{4}\right)_{2} \mathrm{SO}_{4}$ at a final concentration of $50 \%$, crude fractions enriched in IgM or IgG were obtained by gel filtration through Bio-gel A (1.5 m; Bio-Rad Laboratories, Richmond, CA) equilibrated in $20 \mathrm{~m} M$ phosphate buffer, 150 $\mathrm{mM} \mathrm{NaCl}, \mathrm{pH} 7.3$ (PBS). Absence of the other immunoglobulin was checked in both fractions, using Ouchterlony plates developed with precipitating commercial anti-human IgG or IgM antisera (Cappel Laboratories, Malvern, PA). The IgG-enriched fraction was furthier purified by affinity adsorption on protein-A sepharose (Pharmacia, Uppsala, Sweden), resulting in a homogenous population of IgG devoid of IgM, as revealed both by Ouchterlony analysis and SDSPAGE. The IgM-enriched fraction was further passed through a second gel filtration column, using Sepharose Cl-2B (Pharmacia) equilibrated in PBS to remove high-molecular-weight contaminants, and finally purified by ion-exchange chromatography on DEAEsepharose [44] to eliminate $\alpha_{2}$-macroglobulin. When developed in Ouchterlony plates with a polyclonal anti-human IgM antiserum or with a polyclonal anti-whole plasma antiserum, this IgM preparation gave one single line of identity, confirmed by the presence of a single band in SDS-PAGE run in nonreduced conditions.

The final step consisted of affinity purification using J5 LPS-agarose equilibrated in PBS. The affinity resin containing J5 LPS (J5 LPSagarose) was prepared as described [38] after activation of diaminodipropylamine agarose (Pierce Chemical, Rockford, IL) with $6 \%$ glutaraldehyde and coupling with purified core glycolipid in 50 $\mathrm{mM}$ sodium borate buffer ( $\mathrm{pH} 8.2$ ). Both purified IgG and IgM fractions were passed through the affinity column; after loading, the column was extensively washed with PBS before specific anti-LPS antibodies were eluted with $0.1 \mathrm{M}$ glycine-HCl buffer ' $\mathrm{pH} 2.5$ ). Eluted antibodies were immediately neutralized with $1 M$ TRIS and dialyzed against PBS. Specific antibodies were measured $(\mu \mathrm{g} / \mathrm{ml})$ using radial immunodiffusion plates prepared for detection of human IgG or IgM (Nor Partigen, Behring, Germany).

Preparation of LPS-HDL complexes. LPS-HDL complexes were prepared as described [45] (except that $100 \mu \mathrm{g}$ of LPS/ml of plasma was added instead of $10 \mu \mathrm{g}$ ). Briefly, a pool of fresh human plasma was made $20 \mathrm{~m} M$ in EDTA; $100 \mu \mathrm{g}$ aliquots of LPS or lipid A were added for each milliliter of plasma. Incubation was done for $1 \mathrm{~h}$ at $37^{\circ} \mathrm{C}$. LPS-HDL complexes were then isolated by ultracentrifugation with increasing concentrations of potassium bromide $(\mathrm{KBr})$, as described for purification of HDL [46]. In this manner we prepared J5 LPS-HDL, Re LPS-HDL, lipid A-HDL, and O111 LPSHDL complexes and isolated normal HDL as a control for ELISA. After ultracentrifugation in $\mathrm{KBr}$, complexes were dialyzed against $75 \mathrm{~m} M$ TRIS/150 $\mathrm{mM} \mathrm{NaCl}$ (pH 7.3) containing 0.1\% EDTA and kept at $4^{\circ} \mathrm{C}$. The final volume of the solution of purified HDL or HDL-LPS was one-fifth the initial volume of plasma used for the extraction. The amount of LPS within HDL was quantified using radiolabeled LPS.

ELISA. The assay was done in 96-well Immulon ELISA plates (Dynatech Laboratories, Alexandria, VA). For coating with PBS buffer, antigen was dissolved at $10 \mu \mathrm{g} / \mathrm{ml}$ and $100 \mu \mathrm{l}$ aliquots were distributed per well, incubated for $2 \mathrm{~h}$ at $37^{\circ} \mathrm{C}$, and let stand overnight at $4^{\circ} \mathrm{C}$. With LPS-HDL complexes, $100 \mu \mathrm{l}$ aliquots of complexes dissolved 1:200 in PBS were coated in the same way as for native antigen in PBS. For coating in ethanol, $100 \mu \mathrm{l}$ aliquots of antigen dissolved at $10 \mu \mathrm{g} / \mathrm{ml}$ in ethanol were left overnight at room temperature, allowing complete evaporation of the solvent. After antigen coating, plates were shaken empty, extensively washed with PBS, and remaining antigen-attachment sites were blocked by add- 
ing $10 \%$ fetal calf serum in PBS (PBS-FCS) and incubating for 90 min at $37^{\circ} \mathrm{C}$. After additional PBS washings, $100 \mu$ l of test sera diluted in PBS-FCS were added in triplicate and incubation proceeded for $2 \mathrm{~h}$ at $37^{\circ} \mathrm{C}$. The plates were again washed thoroughly with PBS and incubated for $75 \mathrm{~min}$ with a 1:1000 dilution in PBS-FCS of horseradish-peroxidase conjugates of various specificity: These included goat antibodies specific for human $\gamma$ or $\mu$ chain (Sigma), goat antibodies specific for rabbit $\gamma$ chain (Sigma) or rabbit $\mu$ chain (Cappel), and goat antibodies specific for mouse $\gamma$ chain (Sigma). After extensive washing with PBS, substrate $(50 \mathrm{mg} o$-phenylenediamine, $20 \mu \mathrm{l} \mathrm{H}_{2} \mathrm{O}_{2} 30 \%$ (vol $/ \mathrm{vol}$ ) in $60 \mathrm{ml}$ of $50 \mathrm{mM}$ citrate buffer, $\mathrm{pH} 5.5$ ) was added. Enzymatic reaction at room temperature was stopped with $40 \mu \mathrm{H}_{2} \mathrm{SO}_{4} 4 \mathrm{~N}$ after various periods, depending on the intensity of reaction. The $A_{490}$ was measured using a Dynatech MR600 photometer (Dynatech, Chantilly, VA).

After initial studies to determine the optimal conditions of coating, a concentration of $10 \mu \mathrm{g} / \mathrm{ml}$ of free antigens in PBS or ethanol or a dilution of 1:200 of the solution of LPS-HDL in PBS (i.e., 1-2 $\mu \mathrm{g} / \mathrm{ml}$ LPS) was adopted. Controls were included using HDL alone as a solid-phase coating when ELISA was run with LPS-HDL complexes or using buffer or ethanol for the other two techniques. Usually background values ranged between 0.02 to $0.2 A_{490}$, with slightly higher background values with HDL than with the other two techniques. Control values were subtracted from total readings.

\section{Results}

Demonstration of LPS within LPS-HDL complexes. Plasma $(3 \mathrm{ml})$ containing various concentrations of radiolabeled LPS were processed for isolating LPS-HDL complexes. Table 1 shows that $50 \%-85 \%$ of the radioactivity was recovered within the HDL fraction. The final volume of LPS-HDL complexes was one-fifth the initial plasma volume. Since we used an initial concentration of $100 \mu \mathrm{g} / \mathrm{ml}$ LPS in plasma for preparing the LPS-HDL complexes for ELISA, the concentration of LPS within the complexes was between $250 \mu \mathrm{g} / \mathrm{ml}$ for O111 LPS-HDL and $425 \mu \mathrm{g} / \mathrm{ml}$ for lipid A-HDL. When preparing the plates for ELISA, the complexes were diluted $1: 200$, corresponding to a final concentration of $\sim 1-2 \mu \mathrm{g} / \mathrm{ml}$. HDL alone had a pattern identical to that of LPS-HDL complexes after protein staining of samples run in SDS-PAGE. The major protein was apoprotein Al. There was a small band of albumin (data not shown).

Studies with monoclonal antibodies (table 2). Cross-reactions outside the expected specificity were obtained with monoclonal antibodies when ELISAs were done using free LPS either in PBS or in ethanol solvent for coating. The apparent cross-reactivity observed in these conditions was probably an artifact, since $\mathrm{C} 117$ was found to bind to lipid A, whereas it has no specificity for lipid A alone. A similar, probably misleading, cross-reactivity was seen with monoclonal antibody F136, an antibody specific for J5 LPS core sugars; it bound to lipid A, a molecule lacking core sugars. That these findings may be associated with the physicochemical state of LPS is suggested by the observation that the roughest LPS had the strongest apparent cross-reaction; in contrast, non-
Table 1. Amount of radiolabeled lipopolysaccharide (LPS) binding to the high-density lipoprotein (HDL) fraction during the preparation of LPS-HDL complexes.

\begin{tabular}{lcccc} 
& \multicolumn{4}{c}{$\begin{array}{c}\text { Total counts per } \\
\text { minute }(\mathrm{cpm})\end{array}$} \\
Complex & $\begin{array}{c}\text { LPS } \\
\text { added } \\
(\mu \mathrm{g} / \mathrm{ml})\end{array}$ & Plasma & $\begin{array}{c}\text { LPS-HDL } \\
\text { fraction }\end{array}$ & $\begin{array}{c}\% \\
\text { recovered }\end{array}$ \\
\hline J5 $\left[{ }^{3} \mathrm{H}\right]$ LPS & 10 & 7425 & 4070 & 55 \\
Re $\left[{ }^{3} \mathrm{H}\right] \mathrm{LPS}$ & 100 & 77,230 & 43,200 & 56 \\
OII1 $\left[{ }^{3} \mathrm{H}\right]$ LPS & 100 & 75,000 & 59,220 & 79 \\
{$\left[{ }^{51} \mathrm{Cr}\right]$ lipid A } & 100 & 32,500 & 15,980 & 50 \\
& 20 & 15,680 & 13,330 & 85 \\
& 60 & 39,060 & 26,400 & 65 \\
\hline
\end{tabular}

NOTE. A known amount of radiolabeled LPS was added to EDTA plasma, and the total cpm was measured in plasma. The LPS-HDL complexes were then extracted [45]. Total cpm in LPS-HDL fractions was measured and the percentage recovered was calculated as (total cpm in LPS-HDL)/(total cpm in plasma) $\times 100$.

Table 2. Comparison of coating with LPS-HDL complexes or with free LPS for measuring monoclonal antibodies against lipid A or core LPS.

\begin{tabular}{|c|c|c|c|c|c|}
\hline \multirow[b]{2}{*}{ Antigen } & \multicolumn{3}{|c|}{$\begin{array}{l}\text { Mouse monoclonal } \\
\text { IgG }\end{array}$} & \multicolumn{2}{|c|}{$\begin{array}{c}\text { Human monoclonal } \\
\text { IgM }\end{array}$} \\
\hline & $\begin{array}{c}\text { Re LPS } \\
\text { C117 }\end{array}$ & $\begin{array}{c}\text { Lipid A } \\
8 \mathrm{Al}\end{array}$ & $\begin{array}{l}\text { Lipid A } \\
\text { IC3 }\end{array}$ & $\begin{array}{l}\text { J5 LPS } \\
\text { F136 }\end{array}$ & $\begin{array}{l}\text { Lipid A } \\
\text { F117 }\end{array}$ \\
\hline HDL-J5 LPS & 0 & 0 & 0 & $>2$ & 0 \\
\hline HDL-Re LPS & 1.98 & 0 & 0 & 0 & 0.11 \\
\hline HDL-lipid A & 0 & 1.67 & 1.95 & 0.11 & 1.16 \\
\hline HDL-O111 LPS & 0 & 0 & 0 & 0 & 0 \\
\hline J5 LPS* & 0.15 & 0.21 & 0.21 & $>2$ & 0 \\
\hline Re LPS* & 1.98 & 0.12 & 0.30 & 0.09 & 0 \\
\hline Lipid $A^{*}$ & 0.57 & $>2$ & $>2$ & 0.20 & 1.57 \\
\hline O111 LPS* & 0 & 0 & 0 & 0 & 0 \\
\hline J5 LPS ${ }^{\dagger}$ & 0.55 & 0.53 & 0.52 & $>2$ & 0.74 \\
\hline $\operatorname{Re}$ LPS $^{\dagger}$ & 1.84 & 0.86 & 0.82 & 1.04 & 1.74 \\
\hline Lipid $\mathrm{A}^{\dagger}$ & 1.60 & $>2$ & $>2$ & 1.16 & $>2$ \\
\hline 0111 LPS $\dagger$ & 0 & 0 & 0 & 0 & 0.33 \\
\hline
\end{tabular}

NOTE. Values are shown as optical densities (OD) obtained under these conditions: monoclonal antibody concentration, $-0.5 \mu \mathrm{g} / \mathrm{ml}$; dilution of conjugated antibody, 1:1000; incubation of peroxidase substrate, $6 \mathrm{~min}$. Results are expressed after subtraction of background values. OD values $<0.05$ are shown as 0 . LPS, lipopoly saccharide; HDL, high-density lipoprotein.

* Free LPS or lipid A diluted in PBS.

† Free LPS or lipid A diluted in ethanol.

specific binding was not observed when using a hydrophilic antigen like the LPS from the smooth strain $E$. coli 0111 .

In contrast, when ELISAs were done using LPS within HDL complexes for coating, antibodies appeared highly specific for the corresponding antigens. This was the case for monoclonal $\mathrm{C} 117$ directed against Re LPS, monoclonal antibodies 8A1, 1C3, and F117 directed against lipid A, and the monoclonal antibody F136 recognizing J5 LPS. Cross-reactions were nonexistent for IgG antibodies and minimal for IgM antibodies.

Studies with polyclonal rabbit antisera (table 3). Using the various antigens for coating, we evaluated the ELISA pat- 
Table 3. Comparison of coating with LPS-HDL complexes or with free LPS for measuring antibodies against lipid A or core LPS in rabbit sera.

\begin{tabular}{|c|c|c|c|c|c|}
\hline \multirow[b]{2}{*}{$\begin{array}{l}\text { Antibodies, } \\
\text { antigen }\end{array}$} & \multicolumn{4}{|c|}{$\begin{array}{l}\text { Antibodies measured in antisera } \\
\text { from rabbits immunized with }\end{array}$} & \multirow{2}{*}{$\begin{array}{l}\text { Non- } \\
\text { immune } \\
\text { rabbit } \\
\text { sera }\end{array}$} \\
\hline & $\begin{array}{l}\text { E. coli } \\
\mathrm{J} 5\end{array}$ & $\begin{array}{l}\text { LPS } \\
\operatorname{Re}\end{array}$ & Lipid A & $\begin{array}{c}\text { E. coli } \\
\text { O111 }\end{array}$ & \\
\hline \multicolumn{6}{|l|}{ IgG } \\
\hline HDL-J5 LPS & $>2$ & 0 & 0 & 0 & 0 \\
\hline HDL-Re LPS & 0 & $>2$ & 0 & 0 & 0 \\
\hline HDL-lipid A & 0 & 0 & $>2$ & 0 & 0 \\
\hline HDL-O111 LPS & 0 & 0 & 0 & $>2$ & 0 \\
\hline J5 LPS* & 0.82 & 0.18 & 0 & 0 & 0 \\
\hline Re LPS* & 0.17 & 0.94 & 0 & 0 & 0 \\
\hline Lipid $A^{*}$ & 0.08 & 0.26 & 1.07 & 0 & 0 \\
\hline O111 LPS* & 0 & 0.22 & 0 & 1.88 & 0 \\
\hline J5 LPS ${ }^{\dagger}$ & 1.44 & 0.10 & 0.18 & 0 & 0 \\
\hline $\operatorname{Re}$ LPS $\dagger$ & 0.11 & 1.42 & 0.26 & 0 & 0 \\
\hline Lipid $A^{\dagger}$ & 0.33 & 0.55 & $>2$ & 0 & 0 \\
\hline 0111 LPS & 0 & 0 & 0.15 & 0.62 & 0 \\
\hline \multicolumn{6}{|l|}{ IgM } \\
\hline HDL-J5 LPS & $>2$ & 0 & 0.22 & 0 & 0 \\
\hline HDL-Re LPS & 0 & 1.65 & 0.16 & 0 & 0 \\
\hline HDL-lipid A & 0 & 0.85 & $>2$ & 0 & 0 \\
\hline HDL-O111 LPS & 0 & 0 & 0 & $>2$ & 0 \\
\hline J5 LPS* & 1.84 & 0.18 & 0.14 & 0 & 0 \\
\hline Re LPS* & 0.12 & 0.51 & 0.27 & 0 & 0 \\
\hline Lipid $A^{*}$ & 0 & 0.18 & 0.81 & 0 & 0 \\
\hline O111 LPS* & 0 & 0.53 & 0.11 & $>2$ & 0 \\
\hline J5 LPS ${ }^{\dagger}$ & $\$ 2$ & 0.24 & 0.44 & 0.10 & 0.15 \\
\hline Re LPS ${ }^{\dagger}$ & 0.21 & 1.11 & 0.44 & 0 & 0 \\
\hline Lipid $A^{\dagger}$ & 0.21 & 0.70 & 1.22 & 0 & 0.13 \\
\hline O111 LPS $\dagger$ & 0 & 0.34 & 0.42 & 1.89 & 0 \\
\hline
\end{tabular}

NOTE. Optical densities (OD) were measured as follows: dilution of rabbit antisera, 1:500; dilution of conjugated antibody, 1:1000; incubation of peroxidase substrate, $30 \mathrm{~min}$. OD values $<0.05$ are shown as 0 . LPS, lipopolysaceharide; HDL, high-density lipoproteins

* Free LPS or lipid A diluted in PBS buffer.

$\dagger$ Free LPS or lipid A diluted in ethanol."

tern of reactivity of polyclonal antisera from rabbits immunized with $E$. coli $\mathrm{J} 5$ or $E$. coli $\mathrm{O} 111$ whole cells, Re LPS, or lipid A extracted from Re LPS. When free LPS in PBS were used as antigens for coating, cross-reactions were observed both with polyclonal rabbit IgG and IgM, including cross-reactions with O111 LPS. This apparent cross-reactivity was increased when ethanol was used as solvent. As for monoclonal antibodies, when LPS-HDL were used as antigens for coating, polyclonal rabbit IgG showed antibody specificities exclusively directed against the corresponding immunizing antigens. Some cross-reactivity against core LPS antigens was observed when polyclonal rabbit IgM were tested, but no antiserum to core LPS cross-reacted with the smooth O111 LPS.

Studies with human polyclonal antibodies (table 4.) Similar comparisons using various coating conditions for ELISA were done to evaluate the pattern of reactivity of polyclonal human IgG and IgM antibodies. We used IgG and IgM fractions purified from a pool of plasma from human volunteers
Table 4. Comparison of coating with LPS-HDL complexes or with free LPS for measuring antibodies against lipid A or core LPS in humans.

\begin{tabular}{lccccc}
\hline & \multicolumn{2}{c}{$\begin{array}{c}\text { Fractionated } \\
\text { pooled }^{*}\end{array}$} & & \multicolumn{2}{c}{$\begin{array}{c}\text { Immunopurified } \\
\text { anti-J5 LPS }\end{array}$} \\
\cline { 2 - 3 } Antigen & IgG & IgM & & IgG & IgM \\
\hline HDL-J5 LPS & 1.608 & 1.345 & & 0.735 & $>2$ \\
HDL-Re LPS & 0.095 & 0.090 & & 0 & 0 \\
HDL-lipid A & 0.109 & 0 & & 0 & 0 \\
J5 LPS $\ddagger$ & 0.620 & 0.851 & & 0.836 & $>2$ \\
Re LPS & 0.258 & 0.312 & & 0 & 0.130 \\
Lipid A & 0.321 & 0.175 & & 0.118 & 0.166 \\
J5 LPS & 1.029 & 1.110 & & 0.622 & $>2$ \\
Re LPS $\$$ & 0.507 & 0.847 & & 0.067 & 0.326 \\
Lipid A $\$$ & 0.423 & 1.215 & & 0.142 & 0.851 \\
\hline
\end{tabular}

NOTE. Optical densities (OD) are shown after subtraction of background values under these conditions: primary antibody diluted 1:50, conjugates diluted $1: 1000$, incubation with peroxidase substrate $20 \mathrm{~min}$. OD values $<0.05$ are shown as 0 . LPS, lipopolysaccharide; HDL, high-density lipoprotein.

* Total IgG and IgM fractionated from a pool of plasma with a high titer of antibodies against J5 LPS.

Anti-J5 LPS IgG and IgM antibodies were immunopurified from total IgG and IgM fractions using a column of J5-LPS agarose.

‡ Free LPS or lipid A diluted in PBS buffer.

$\S$ Free LPS or lipid A diluted in ethanol.

vaccinated with $E$. coli $\mathrm{J} 5$. In addition, each immunoglobulin fraction was affinity-purified through J5 LPS-agarose and tested in the various ELISA conditions. The contents of antiRe LPS or anti-lipid A antibodies in both total IgG or IgM pools appeared considerably higher when free LPS in PBS or ethanol were used for coating than when LPS-HDL complexes were used. Similarly, immunopurified anti-J5 LPS human IgG or IgM had apparent cross-reactivity when free antigens in ethanol or PBS were used for coating. Here again, this cross-reactivity was more important for IgM than for IgG. In contrast, when using LPS-HDL complexes for coating, immunopurified anti-J5 LPS IgG or IgM were exclusively directed against J5 LPS and did not cross-react with Re LPS or lipid $\mathrm{A}$.

\section{Discussion}

The existence of a broad cross-reactivity of core LPS antibodies has not been unequivocally shown so far because of the difficulty in demonstrating in vitro that polyclonal or monoclonal antibodies to core LPS can bind to a variety of LPS extracted from smooth strains [1, 6-13]. In addition, although the structure of the core LPS or of the lipid A is more conserved than that of the $\mathrm{O}$-side chains, there is nevertheless significant variability among strains. Recently, in a study of 29 murine monoclonal core LPS antibodies, Pollack et al. [12] found that cross-reactivity was restricted by inter- and intraspecies differences in covalent core structures and by epi: tope concealment by overlying $\mathrm{O}$-side chains and core sugars. However, it has been argued that the LPS usually used for in vitro studies of cross-reactivity were extracted from 
stationary-phase bacteria and might therefore differ from the LPS harbored by bacteria during infectious processes. Indeed, core LPS determinants may be more exposed on LPS from growing bacteria [26] or from bacteria submitted to antibiotic drugs [47] than from stationary-phase bacteria.

Although the controversies about in vitro cross-reactivity of core LPS antibodies are not resolved, recent studies with monoclonal antibodies $[29,48]$ seem to support the concept that core LPS antibodies can be cross-protective in vivo. However, the results of animal experiments in this field are subject to caution because the published data have not always been replicated $[8,20,49-54]$. Thus, the adequate characterization of the binding specificities of antibodies directed against core LPS or lipid A constitutes an important prerequisite for the understanding of their biologic role. To detect crossreactive antibodies of the various immunoglobulin classes, ELISA appears more appropriate than hemagglutination assays, which measure predominantly IgM antibodies, or than passive hemolysis assays, which cannot discriminate between immunoglobulin classes.

We investigated various ELISA conditions, considering a factor that has recently been emphasized, that LPS from rough strains are hydrophobic structures that can have significant variability of their physical properties (e.g., their degree of hydration and state of aggregation) depending on how they are prepared and diluted. These physical properties have a profound impact on their biologic activities [55-57] and, at least for lipid $\mathrm{A}$, on the nonspecific binding of antibodies to it [23].

There are at least three reasons why LPS-HDL complexes may improve the presentation of LPS to antibodies in ELISA. (1) Due to the physicochemical properties of the complexes, exposure of hydrophilic determinants would favor the binding of specific antibodies while masking the hydrophobic structures that promote nonspecific binding [23]. In addition, the protein content of the LPS-HDL complexes could improve the reliability of the coating of core LPS to plastic surfaces. (2) The preparation of LPS-HDL complexes includes an ultracentrifugation step on $\mathrm{KBr}$ gradient that might remove proteins and nucleic acids that are coextracted with LPS during the standard extraction procedures. For instance, phenolextracted LPS (Sigma) has a bacterial protein content of $0.5 \%-3 \%$ and a bacterial RNA content of $0.5 \%-3 \%$. These amounts of contaminants may be sufficient to cause significant reactions with antibodies in ELISA when 10-100 $\mu \mathrm{g}$ of LPS $/ \mathrm{ml}$ are used for coating, since proteins are better coating agents than LPS. (3) HDL is an important physiologic carrier of LPS in serum $[38,39]$ : If cross-reactive antibodies can act as neutralizing antibodies in protection against endotoxin shock, they would recognize exposed LPS epitopes within LPS-HDL complexes.

In the present experiments, when free lipid A or free core LPS diluted in PBS buffer or in ethanol were used for coating ELISA plates, cross-reactive bindings against core LPS or lipid A were detected in various core LPS antisera, immunoglobulin preparations, or monoclonal antibodies. In contrast, when using LPS-HDL complexes as antigens, the same antibody preparations showed a very narrow specificity that was restricted to the antigens used for immunization. One possible explanation for the cross-reactivity detected when using free LPS for coating was that nonspecific binding of antibodies occurred due to the exposure of the hydrophobic deepest parts of LPS on the ELISA plates. In support of that explanation was the pattern of reactivity of the monoclonal antibodies, particularly of $\mathrm{Cl} 17$ whose precise specificity is known in detail. The epitope of this anti-Re LPS antibody is part of lipid A and part of the KDO disaccharide. This clone does not recognize lipid A alone or J5 LPS [43].

The methodology used to define the specific epitope of $\mathrm{Cl} 17$ involved inhibition studies and gel precipitation using chemically defined KDO and lipid A-derived synthetic molecules [58]. Thus the reactivity of $\mathrm{C} 117$ to free lipid A in the present experiments showed the apparent artifactual nature of this binding. Of particular relevance is our finding that when the binding of C117 was measured using ethanol-coated LPS or lipid A ELISA plates, the nonspecific interaction observed between C117 and lipid A was nearly the same magnitude as its specific interaction with Re LPS. Therefore, our data demonstrate that apparently false cross-reactivities of core LPS antibodies may occur with standard ELISA, a phenomenon that was absent or minimal when LPS-HDL complexes were used for coating.

A possible explanation for the lack of broad cross-reactivity of anti-core LPS antibodies in the assay with LPS-HDL complexes may be the hiding of LPS epitopes within the HDL molecule. For $\mathrm{Cl17}$, this explanation is unlikely because it was shown by other methods that this antibody does not specifically recognize lipid $A$. The observed lack of binding of this clone to HDL-lipid A was therefore most likely due to the abolishment of nonspecific interactions. With the other antibodies or antisera, the possibility that epitopes were concealed within HDL complexes seemed unlikely since the specifically defined antibodies reacted fully against their corresponding antigens within HDL complexes. In addition, the specific reactions were more pronounced as revealed by higher optical density values when using LPS-HDL complexes as antigens than when using free LPS, perhaps because the exposure of hydrophilic antigenic determinants was favored in LPS-HDL complexes. Therefore, by analogy with the findings with $\mathrm{C117}$, the apparent cross-reactivity observed when the other antibodies were tested with free core LPS probably resulted from nonspecific interactions.

Although we have tested only one LPS extracted from a smooth strain, $E$. coli $\mathrm{O} 111$, the absence of cross-reactivity of core LPS antibodies with this LPS is of particular relevance because the strain is the parent of the rough mutant $\mathrm{J} 5$ and has been extensively studied in protection experiments in animals, including in experiments with purified O111 LPS prepared by the same method as the LPS used in our ELISA 
[2, 48, 59-61]. Since the core LPS antibodies or antisera, which seemed protective in vivo against O111 LPS, did not recognize it in vitro, the mechanisms responsible for the in vivo protection demonstrated by others remain enigmatic.

Our data do not rule out the possibility that cross-reactivity might be demonstrated in other systems nor do they exclude the possibility that HDL may prevent some cross-reactive sites from interacting with antibody. However, the present study demonstrates that apparently artefactual cross-reactivities of core LPS antibodies may be shown by standard ELISA and that the use of LPS-HDL complexes as coating antigens significantly decreases this phenomenon. Therefore, the results of experiments of cross-reactivities performed with ELISA using free core LPS or lipid A as coating antigens must be interpreted with caution. Indeed, definite proof for true crossreactive antibodies requires measurements of affinity constants for clearly defined epitopes within the LPS molecule.

\section{Acknowledgment}

We thank R. J. Ulevitch for helpful suggestions and for the gift of $\left[{ }^{3} \mathrm{H}\right]$ Re LPS, B. J. Appelmelk for the gift of monoclonal antibody $\mathrm{C117}$, and $\mathrm{A}$. Golay for help in isolating HDL complexes.

\section{References}

1. Chedid L, Parant M, Boyer F. A proposed mechanism for natural immunity to enterobacterial pathogens. J Immunol 1968;100:292-301.

2. Braude AI, Douglas H. Passive immunization against the local Shwartzman reaction. J Immunol 1972;108:505-12.

3. McCabe WR. Immunization with R mutants of $S$. minnesota. I. Protection against challenge with heterologous gram-negative bacilli. J Immunol 1972;108:601-10.

4. Ziegler EJ, McCutchan JA, Fierer J, et al. Treatment of gram-negative bacteremia and shock with human antiserum to a mutant Escherichia coli. N Engl J Med 1982;307:1225-30.

5. Baumgartner JD, Glauser MP, McCutchan JA, et al. Prevention of gramnegative shock and death in surgical patients by prophylactic antibody to endotoxin core glycolipid. Lancet 1985;2:59-63.

6. De Jongh-Leuvenik J, Vreede RW, Marcelis JH, de Vos M, Verhoef J. Detection of antibodies against lipopolysaccharides of Escherichia coli and Salmonella $\mathrm{R}$ and $\mathrm{S}$ strains by immunoblotting. Infect Immun 1985;50:716-20.

7. Johns MA, Bruins SC, McCabe WR. Immunization with R mutants of Salmonella minnesota. II. Serological response to lipid $A$ and the lipopolysaccharide of Re mutants. Infect Immun 1977;17:9-15.

8. Ng AK, Chen CLH, Chang CM, Nowotny A. Relationship of structure to function in bacterial endotoxins: serologically cross-reactive components and their effect on protection of mice against some gramnegative infections. J Gen Microbiol 1976;94:107-16.

9. Siber GR, Kania SA, Warren HS. Cross-reactivity of rabbit antibodies to lipopolysaccharide of Escherichia coli $\mathrm{J} 5$ and other gram-negative bacteria. J Infect Dis 1985;152:954-64.

10. Schwartzer TA, Alcid DV, Numsuwan V, Gocke DJ. Immunochemical specificity of human antibodies to lipopolysaccharide from the J5 rough mutant of Escherichia coli O111:B4. J Infect Dis 1989;159:35-42.

11. Gigliotti F, Shenep JL. Failure of monoclonal antibodies to core glycolipid to bind intact strains of Escherichia coli. J Infect Dis 1985;151:1005-11.

12. Pollack M, Chia JKS, Koles NL, Miller M, Guelde G. Specificity and cross-reactivity of monoclonal antibodies reactive with the core and lipid A regions of bacterial lipopolysaccharide. J Infect Dis 1989;159:168-88.

13. Shenep JL, Gigliotti F, Davis DS, Hildner WK. Reactivity of antibodies to core glycolipid with gram-negative bacteria. Rev Infect Dis 1987;9(suppl):S639-43.

14. Young LS, Hoffman KR, Stevens P. Core glycolipid of enterobacteriaceae: immunofluorescent detection of antigen and antibody. Proc Soc Biol Med 1975;149:389-96.

15. Eskenazy M, Konstantinov G, Ivanova R, Strahilov D. Detection by immunofluorescence of common antigenic determinants in unrelated gram-negative bacteria and their lipopolysaccharides. J Infect Dis 1977;135:965-9.

16. Nixdorff KK, Schlecht SS. Heterogeneity of the haemagglutinin responses to Salmonella minnesota $\mathrm{R}$ antigens in rabbits. J Gen Microbiol 1972;71:425-40.

17. Bruins SC, Ingwer I, Zeckel ML, White AC. Parameters affecting the enzyme-linked immunosorbent assay of immunoglobulin $G$ antibody to a rough mutant of Salmonella minnesota. Infect Immun 1978;21:721-8.

18. Miner KM, Manyak CL, Williams E. Characterization of murine monoclonal antibodies to Escherichia coli J5. Infect Immun 1986;52:56-62.

19. Galanos C, Luederitz $O$, Westphal $O$. Preparation and properties of antisera against the lipid-A component of bacterial lipopolysaccharides. Eur J Biochem 1971;24:116-22.

20. Hodgin LA, Drews J. Effect of active and passive immunizations with lipid A and Salmonella minnesota Re 595 on gram-negative infections in mice. Infection 1976;4:5-10.

21. Mattsby-Baltzer I, Alving CR. Antibodies to lipid A: occurrence in humans. Rev Infect Dis 1984;6:553-7.

22. Brade $L, B r a d e ~ H$. Characterization of two different antibody specificities recognizing distinct antigenic determinants in free lipid A of Escherichia coli. Infect Immun 1985;48:776-81.

23. Brade L, Brandenburg $\mathrm{K}$, Kuhn HM, et al. The immunogenicity and antigenicity of lipid $A$ are influenced by its physicochemical state and environment. Infect Immun 1987;55:2636-44.

24. Mattsby-Baltzer I, Kaijser B. Lipid A and anti-lipid A. Infect Immun 1979;23:758-63.

25. Baumgartner JD, O'Brien TX, Kirkland TN, Glauser MP, Ziegler EJ. Demonstration of cross-reactive antibodies to smooth gram-negative bacteria in Escherichia coli J5 antiserum. J Infect Dis 1987;156:136-43.

26. McCallus DE, Norcross NL. Antibody specific for Escherichia coli J5 cross-reacts to various degrees with an Escherichia coli clinical isolates grown for different lengths of time. Infect Immun 1987;55:1042-6.

27. Mutharia LM, Crockford G, Bogard C Jr, Hancock REW. Monoclonal antibodies specific for Escherichia coli J5 lipopolysaccharide: crossreaction with other gram-negative bacterial species. Infect Immun 1984;45:631-6.

28. Nelles MJ, Niswander CA. Mouse monoclonal antibodies reactive with J5 lipopolysaccharide exhibit extensive serological cross-reactivity with a variety of gram-negative bacteria. Infect Immun 1984;46: 677-81.

29. Dunn DL, Bogard WC, Cerra FB. Efficacy of type-specific and crossreactive murine monoclonal antibodies directed against endotoxin during experimental sepsis. Surgery 1985;98:283-9.

30. Bogard WC, Dunn DL, Abernethy K, Kilgarriff C, Kung PC. Isolation and characterization of murine monoclonal antibodies specific for gram-negative bacterial lipopolysaccharide: association of cross-genus reactivity with lipid A specificity. Infect Immun 1986;55:899-908.

31. Pollack M, Huang AI, Prescott RK, et al. Enhanced survival in Pseudomonas aeruginosa septicemia associated with high levels of circulating antibody to Escherichia coli endotoxin core. J Clin Invest 1983;72:1874-81.

32. Law BJ, Marks MI. Age-related prevalence of human serum IgG and IgM antibody to core glycolipid of Escherichia coli J5, as measured by ELISA. J Infect Dis 1985;151:988-94. 
33. Nys M, Damas P, Damas F, Joassin L, Demonty J. A direct enzymelinked immunosorbent assay (ELISA) for antibodies to enterobacterial Re core glycolipid and lipid A. Med Microbiol Immunol 1987;176:257-71.

34. Vanesian MA, Fung G, Bagdasarian A. Enzyme immunoassay for the quantitation of immunoglobulin M class antibodies to Salmonella minnesota R595 and Escherichia coli J5 lipopolysaccharides. Diag Microbiol Infect Dis 1987;6:11-25.

35. Appelmelk BJ, Verweij-von Vught AMJJ, MacLaren DM, Thijs LG. An enzyme-linked immunosorbent assay (ELISA) for the measurement of antibodies to different parts of the gram-negative lipopolysaccharide core region. J Immunol Methods 1985;82:199-207.

36. Kirkland TN, Colwell DE, Michalek SM, McGhee JR, Ziegler EJ. Analysis of the fine specificity and cross-reactivity of monoclonal antilipid A antibodies. J Immunol 1986;137:3614-9.

37. Appelmelk BJ, Gruteke P, Verweij-von Vught AMJJ, Maaskant JJ, Thijs LG, MacLaren DM. Measurement in human sera of antibodies to lipopolysaccharide of Escherichia coli J5. Microb Pathog 1987; 2:391-3.

38. Ulevitch RJ, Johnston AR, Weinstein DB. New functions for high density lipoproteins. Isolation and characterization of a bacterial lipopolysaccharide-high density lipoprotein complex formed in rabbit plasma. J Clin Invest 1981;67:827-37.

39. Tobias PS, McAdam KPWJ, Soldau K, Ulevitch RJ. Control of lipopolysaccharide-high density lipoprotein interactions by an acute-phase reactant in human serum. Infect Immun 1985;50:73-6.

40. Westphal O, Luederitz O, Bister F. Über die Extraktion von Bakterien mit Phenol/Wasser. Z Naturforsch [c] 1952;7:148-55.

41. Larsen NE, Sullivan $R$. Interaction between endotoxin and human monocytes: characteristics of the binding of ${ }^{3} \mathrm{H}$-labeled lipopolysaccharide and ${ }^{51} \mathrm{Cr}$-labeled lipid $\mathrm{A}$ before and after the induction of endotoxin tolerance. Proc Natl Acad Sci USA 1984;81:3491-5.

42. Appelmelk BJ, Verweij-von Vught AMJJ, Maaskant JJ, Schouten WF, Thijs LG, MacLaren DM. Monoclonal antibodies detecting novel structures in the core region of Salmonella minnesota lipopolysaccharide. FEMS Microbiol Lett 1987;40:71-4.

43. Rozalski A, Brade L, Kosma P, Appelmelk BJ, Krogmann C, Brade H. Epitope specificities of murine monoclonal and rabbit polyclonal antibodies against enterobacterial lipopolysaccharides of the Re chemotype. Infect Immun 1989;57:2645-52.

44. Jehanli A, Hough D. A rapid procedure for the isolation of human IgM myeloma proteins. J Immunol Methods 1981;44:199-204.

45. Tobias PS, Ulevitch RJ. Control of lipopolysaccharide-high density lipoprotein binding by acute-phase proteins(s). J Immunol 1983;131: 1913-6.

46. Havel RJ, Eder HA, Bragdon JH. The distribution and chemical composition of ultracentrifugally separated lipoproteins in human serum. $\mathrm{J}$ Clin Invest 1955;34:1345-53.
47. Overbeck BP, Schellekens JFP, Lippe W, Dekker BAT, Verhoef J. Carumonam enhances reactivity of Escherichia coli with mono- and polyclonal antisera to rough mutant Escherichia coli J5. J Clin Microbiol 1987;156:136-43.

48. Teng NNH, Kaplan HS, Hebert JM. Protection against gram-negative bacteremia and endotoxemia with human monoclonal IgM antibodies. Proc Natl Acad Sci USA 1985;82:1790-4.

49. Greisman SE, DuBuy JB, Woodward CL. Experimental gram-negative bacterial sepsis: reevaluation of the ability of rough mutant antisera to protect mice. Proc Soc Biol Med 1978;158:482-90.

50. Pennington JE, Menkes E. Type-specific versus cross-protective vaccination for gram-negative pneumonia. J Infect Dis 1981;144:599-603.

51. Peter G, Chernow M, Keating MH, Ryff JC, Zinner SH. Limited protective effect of rough mutant antisera in murine Escherichia coli bacteremia. Infection 1982;10:228-32.

52. Trautmann M, Hahn H. Antiserum against Escherichia coli J5: a reevaluation of its in vitro and in vivo activity against heterologous gramnegative bacteria. Infection 1985;13:140-5.

53. Greisman SE, Johnston CA. Failure of antisera to J5 and R595 rough mutants to reduce endotoxemic lethality. J Infect Dis 1987;157:54-64.

54. Baumgartner JD, Heumann D, Gerain J, Weinbreck P, Grau GE, Glauser MP. Association between protective efficacy of anti-lipopolysaccharide (LPS) antibodies and suppression of LPS-induced tumor necrosis factor $\alpha$ and interleukin 6. Comparison of $O$ side chain-specific antibodies with core LPS antibodies. J Exp Med 1990;171:889-96.

55. Peterson AA, Haug A, McGroarty EJ. Physical properties of short- and long-O-antigen-containing fractions of lipopolysaccharide from Escherichia coli O111:B4. J Bacteriol 1986;165:116-22.

56. Wilson ME, Morrison DC. Evidence for different requirements ị physical state for the interaction of lipopolysaccharides with the classical and alternative pathways of complement. Eur J Biochem 1982;128:137-41.

57. Galanos $\mathrm{C}$, Luederitz $\mathrm{O}$. Electrodialysis of lipopolysaccharides and their conversion to uniform salt forms. Eur J Biochem 1975;54:603-10.

58. Brade L, Kosma BJ, Appelmelk BJ, Paulsen H, Brade H. Use of synthetic antigens to determine the epitope-specificities of monoclonal antibodies against the 3-deoxy-D-manno-octulosonate region of bacterial lipopolysaccharide. Infect Immun 1987;55:462-6.

59. Braude AI, Douglas H, Davis CE. Treatment and prevention of intravascular coagulation with antiserum to endotoxin. $J$ Infect Dis 1973;128:(suppl)157S-64.

60. Ziegler EJ, Douglas H, Sherman JE, Davis CE, Braude AI. Treatment of $E$. coli and Klebsiella bacteremia in agranulocytic animals with antiserum to a UDP-Gal-epimerase-deficient mutant. J Immunol 1973;111:433-8.

61. Ziegler EJ, Douglas H, Braude AI. Human antiserum for prevention of the local Shwartzman reaction and death from bacterial lipopolysaccharides. J Clin Invest 1973;52:3236-8. 